\title{
Samuel Beckett's trilogy and the revolution of the body in Vichy France
}

Article

Accepted Version

Davies, W. (2020) Samuel Beckett's trilogy and the revolution of the body in Vichy France. Twentieth-Century Literature, 66 (1). pp. 11-36. ISSN 0041-462X doi:

https://doi.org/10.1215/0041462X-8196685 Available at https://centaur.reading.ac.uk/89131/

It is advisable to refer to the publisher's version if you intend to cite from the work. See Guidance on citing.

To link to this article DOI: http://dx.doi.org/10.1215/0041462X-8196685

Publisher: Hofstra University

All outputs in CentAUR are protected by Intellectual Property Rights law, including copyright law. Copyright and IPR is retained by the creators or other copyright holders. Terms and conditions for use of this material are defined in the End User Agreement.

\section{www.reading.ac.uk/centaur}

\section{CentAUR}

Central Archive at the University of Reading

Reading's research outputs online 


\section{Samuel Beckett's Trilogy and the Revolution of the Body in Vichy France}

After the defeat of France by Nazi Germany in 1940, the interwar government of the Third Republic was replaced by a collaborationist, authoritarian regime headed by Marshal Phillippe Pétain, operating out of the spa town of Vichy between 1940 and 1944. On coming to power, the ruling elite of the newly formed État français government levelled blame for the fall of the nation at what was proclaimed as the decline of the French race under the liberal, intellectual culture of the Third Republic. Pétain's government sought to regenerate the French nation through its Révolution nationale, a traditionalist, nationalist, antidemocratic campaign of reforms and propaganda that would inculcate three principles into the heart of French life: "Travail, famille, patrie." Although the Vichy government became largely a puppet cabinet after 1942, the ideology and rhetoric of the "revolution" remained in place throughout the rest of the war as part of Vichy's vision of a France fit to join a Europe under Nazi rule. At the center of this vision of a "new" France was the refined French male body, one that was healthy, reproductive and devoted to physical labor and patriotic duties. It was to be "more national, more virile, more human" (Pétain 1942, quoted in Gerber 2018, $11)$.

Against this backdrop, there is something oddly defiant, even resistant, about Samuel Beckett's post-war depictions of physically debilitated and suffering bodies, both on stage and in his prose works. ${ }^{2}$ Critical attention has revealed much about the importance of the body to Beckett's aesthetic and illuminated how the author's work reflects the extent to which "the body has become central to numerous artistic, critical, ethical, scientific and medical discourses and practices" (McMullan 2010, 2) ${ }^{3}$ Like the pained, limping or immobile figures in works such as Waiting for Godot and Endgame, the bodies in Beckett's post-war trilogy of novels published in the fifties-Molloy, Malone Dies and The 
Unnamable — are presented with an emphasis on physical limitation, weakness, and absent body parts; these physical forms parallel the increasing instability of linguistic expression which pervade the texts. ${ }^{4}$ As Shane Weller puts it, these bodily forms "resist the very principle of identity that would govern every system, not least the totalitarian systems that came to dominate the century" $(2009,32)$. Such a resistance emerges because "on closer inspection, the unruliness of the body also forms its dissident and individuating power" (Maude 2009, 112), a process whereby Beckett's bodies exemplify what Rachel Russell identifies more broadly as the "demands of rapidly changing cultural norms and values" $(2000,108)$ in the construction of the modern body against normative, traditional parameters. My concerns in this article are the particular historical conditions of Vichy as a part of the network of contexts that surrounds the "unruliness" of the bodies in the post-war prose. Specifically, I examine the trilogy's extreme imaginings of physical decay and the ways in which these offer a rejection of normative expectations of health and physical fitness which, when reinserted into the historical contexts of Vichy and its propaganda campaigns, translate into a potentially defiant politics of the body that disrupts the "social certainty" (Russell $2000,108)$ of the healthy body that Vichy imagined in nationalist and authoritarian terms. This article follows Andrew Gibson's analysis (2015) of Beckett's short prose works of the forties as responses to Vichy body politics. While Gibson focuses on the linguistic resonances of Beckett's French writing with Vichy discourse, this article's primary concern is with the imagery generated by Beckett's descriptions of the body, particularly as they relate to propaganda images.

Written in Paris following the Liberation, Molloy, Malone Dies, and The Unnamable chart a degeneration of language and narrative which is mirrored in the steady decay of the physical forms of the texts' narrators as they reach towards a silence of mind, body and speech, to "finish dying," as Molloy puts it (2009a, 3). While the still prevalent critical 
position on these texts is of a philosophical kind which suggests that they exemplify what Angela Moorjani calls a "writerly practice that makes a virtue of impasse, failure, and the aporetic method of discouraging reduction to the identical" $(2015,19)$, recent scholarship has begun to tease out the historical resonances of Beckett's writing, a process that acknowledges the warning of "reduction" yet is compelled by the extent to which a "virtue of impasse" might yield its own productive insights when seen as a negotiation of historical events.

By far the majority of historicizing criticism on Beckett's work remains focused on the extent to which his writing engages with the cultural and political narratives of modern Ireland. Patrick Bixby's work (2009) registers the historical implications of Beckett's experimentation with language and the novel form, particularly in the trilogy, and demonstrates the significant ways in which the novels disrupt traditional expectations of identity formation as found in canonical Western culture. This attention to form has been accompanied by various examinations of the political realities of post-colonial Ireland that surrounded and informed Beckett's life and creative practices. ${ }^{5}$ However, if the three novels both directly and obliquely evoke the Ireland of Beckett's youth and education, they also bear the marks of his experiences of France during the war. With this in mind, I suggest that Beckett's texts engage as much with the "foundational values" (Bixby 2009, 27) of both Western literary culture and the Irish Free State as they do the values that compelled the Vichy regime which Beckett and his partner Suzanne Déchevaux-Dumesnil encountered in a limited way as Resistance members in Paris and then most readily as refugees in Southern France. $^{6}$

Scholars such as Lois Gordon (1998), Marjorie Perloff (1996; 2005), Laura Salisbury (2014), Andrew Gibson (2010; 2014; 2015) and Emilie Morin (2017) have illuminated much in reading Beckett's works through a French wartime lens. However, the ideology of Vichy and its material propaganda remains an under-considered area. ${ }^{7}$ In part, this might be due to 
the apparent historical disparity between Vichy's existence as an active regime and Beckett's writing of the post-war texts themselves: ${ }^{8}$ why would Beckett's work continue to negotiate, mock, even resist, political ideas that were no longer dominating the political landscape of France under the restored Republic? Why, in short, would Beckett continue to negotiate a regime that had been defeated? In the first instance, Beckett's creative imagination throughout his career made use of all manner of sources combined in myriad ways: as late as his last prose piece, Stirrings Still (1989), he drew on his memories of his time working in Saint-Lô in $1945 .{ }^{9}$ More directly though, the end of the war, the moment in which Beckett began writing his post-war works, was a period of immense upheaval and tension. The occupiers and the Vichy regime were gone but not forgotten, and Beckett returned to a nation much changed by the war: "All the wrong things, all the wrong way. It is hard sometimes to feel the France that one clung to, that I still cling to," he wrote to Thomas MacGreevy on 4th January $1948(2011,72)$.

The nation had changed irreparably. Though by 1942 the Vichy regime had become largely powerless due to further Nazi occupation, it had bludgeoned the populace throughout the nation with racist and nationalist dogma such that the French public had grown increasingly passive to these aspects of Vichy (Kedward, 1993, 5). If the post-war violence of the purges represented a reaction against collaboration with the occupiers, the rapid accommodation and eventual indifference towards Vichy's "revolution" during the war represented a more disquieting aspect of the French populace (5). Vichy's was a vision of France which Beckett would have detested for its authoritarian nationalism, reactionary traditionalism and overt collaboration, but it was also a France in which he could be actively persecuted for his politics, social connections and avant-garde cultural sensibilities. Alongside their affiliations with the Resistance, Beckett's partner, Suzanne, was in danger 
throughout the war for her direct Communist links. Beckett had also lost friends to the antiSemitic doctrines shared by Vichy and the occupying Nazi forces (Morin 2017, 157).

Though the regime was defeated, the trials and purges of the post-war period also kept Vichy firmly in public consciousness. Vichy was a manifestation of the conservative French public and political classes hostility to the liberal, progressive, intellectual culture of the Third Republic, but it also arose out the desire for stability brought about by the nation's collapse in 1940. The allure of the authoritarian focus on order makes it ideal for crisis, and Vichy propaganda presented its authoritarian nationalism as a source of peace. Beckett was all too aware of that allure and its expression in propaganda, of the Nazi "litany" (Nixon $2011,86)$ he heard recited by citizens in Germany in the late 30s, of the appeal such narratives could have in times of chaos and how they could influence thought and values. Beckett described Pétain after the war as "the poor old misled man and hero of Verdun" $(2011,19)$, drawing together the heroic characterization around which Pétain's authority was constructed with the very prospect that he himself had been swayed by the allure of the propaganda and political rhetoric that his regime had sanctioned. Beckett's phrasing echoes the broader sense that the France he and so many others "clung to" had been "misled" in its turn to the authoritarian nationalism of Vichy after the nation's defeat. ${ }^{10}$

A rejection of the social and cultural narratives at the core of Vichy's propaganda manifests in the impaired bodies of Beckett's post-war writing. They articulate a resistance by producing what Gibson calls

a kind of weird, ironical hymn to incapacity, to the 'second-rate' or 'defective' body, the base, sometimes outrageously or hilariously base body. They are possessed by a sheer if twisted glee at being definitively outside the normative, however shadowed by ills. $(2015,295)$ 
By presenting various images of bodily "incapacity," Beckett's texts confront the conflation of physical strength with moral and social value. The ideal French body under Vichy was one such image; Beckett's rejection of such an ideal manifests, both gleefully and seriously, in the decaying bodies of his trilogy.

To demonstrate more fully the political and historical significance of the body in Beckett's post-war prose, this article considers the trilogy within the context of the pervasive propaganda of masculinity by the Vichy regime and its drive for national renewal, positioning Beckett's male bodies in his prose against the regime's Révolution nationale and its images of the "perfect" French physical form, an ideal which has its origins in French preoccupations with racial degeneration that emerged after World War I. The article uses this context of the Révolution nationale to reveal the ways in which Beckett's male forms defy expectations of the healthy, masculine body which Vichy propaganda emphasized, and the inherent power dynamics that such conditions create. Read in the context of Vichy's renewal campaign, Beckett's move from the limping Molloy to the bed-bound Malone and finally to the physically limbless figure of The Unnamable offers a startling rejection of the pervasive image of the virile male body that circulated in war-time France.

\section{Revolution, Regeneration, Renewal}

\section{[image]}

Fig. 1, "Révolution nationale," poster designed by R. Vachet (Avignon: National Revolution Propaganda Center, n.d., circa 1940)

Once Pétain's government took power, the Révolution nationale came into immediate effect. In a flurry of propaganda, Vichy declared a program of social, economic and political restructuring which would bring France out from the shadow of defeat by focusing the nation 
on physical work, family, national culture, and militaristic hierarchy, and by rejecting a cosmopolitan, international image of the nation (fig. 1). The emphasis on "French" values in the Révolution nationale propaganda campaign is key to understanding the extent to which Vichy's primary goal was to 'regenerate' France from its apparent decline under the Third Republic. In doing so, Vichy revealed its own nationalist and authoritarian agenda that was distinct from the Nazi regime with which it collaborated. ${ }^{11}$ Vichy was, like Nazi Germany, virulently anti-Semitic, and was compelled by what the proto-fascist commentator Charles Maurras described as a fight for France against the "four confederate states of Protestants, Jews, Freemasons and foreigners" (quoted in Junyk 2013, 16). Yet, while state collaboration with Nazi Germany—-both in Vichy and the occupied zone_-represented a participation in and sanctioning of extermination practices, the Révolution nationale itself was a publicfacing campaign that pursued racial reimagining primarily through attempts to reform the values that underpinned the French nation and populace. This was to be achieved through the positive encouragement of economic, social and cultural measures such as youth groups, labor reforms, and veterans' associations, and the negative characterization of 'undesirable' bodies in France and their effects on national wellbeing. For the governing circles of Vichy, French racial stock was diminished largely because the Third Republic had made national virtues of indulgence, decadence and the trappings and comforts of modernity. This is not to say that ideas of racial eradication or sterilization did not exist in French public discourse; Alexis Carrel's Foundation for the Study of Human Problems (Fondation pour l'étude des problèmes humains), established in 1941, for example, is indicative of a more extreme eugenic tendency in French right-wing anthropological thinking that gained currency during the war. However, as Julian Jackson demonstrates, “[t]he real significance of the Fondation Carrel was to provide a quasi-scientific legitimization of the traditionalist agenda of the National Revolution" $(2003,329) .{ }^{12}$ Rather than eradication, Vichy's public rhetoric declared 
that it would change France by "restoring" its values and political structures in order to wrestle control into the hands of "true" French citizens. Distinguishing Vichy's authoritarianism from the fascism of Nazi German is not to absolve Vichy of its collaborating in deportations that were death sentences in all but name, but to emphasize the particular nuances of the publicly authoritarian, traditionalist vision of France and the French people that the Révolution nationale represented. ${ }^{13}$

The speed with which Vichy disseminated its propaganda following the 1940 defeat would have made the Révolution nationale an unavoidable presence during Beckett's experiences in both Paris and the unoccupied zone: "the regime's propaganda was on a scale unprecedented in France," with posters blanketing city walls and village noticeboards alike (Jackson 2003, 253). Vichy took over press outlets - including Harvas, the national independent press agency — and remodeled them as dispensers of notes d'orientation that detailed the ambitions of the revolution and the ills of the Third Republic. Propaganda documents were distributed throughout France, not just the Vichy-controlled south, much to the chagrin of the occupying Nazi forces in the North. ${ }^{14}$ It was in the south, though, that Vichy had complete governance over broadcasts, newsreels and censorship, all of which remained under its control after the Nazi occupation of the region in 1942 (Jackson 2003, 255). Following the collapse of his Resistance cell in Paris, Beckett and Suzanne fled the north in September 1942 and remained in the relative safety of a hilltop village in Roussillon in the far south of France until the end of 1944. Though this part of what Beckett later called the "so-called unoccupied zone" (quoted in Knowlson 1996, 308) offered sanctuary of a sort, the pervasive nature of Vichy's propaganda rendered the Révolution nationale inescapable. ${ }^{15}$

\section{"Health, Courage, Discipline": Vichy Masculinity}


One of the primary preoccupations of Vichy's project of national revival was its concern with French masculinity and the French male body. The condition of French masculinity as supposedly weakened by modernity was cited as a major cause of the French army's collapse against the Nazi military campaign. As Joan Tumblety writes, “[Vichy’s] observations of poor male physique routinely functioned not only as an explanation for military defeat but as a rationale for a certain model of national renewal" $(2012,205)$.

This preoccupation with the male body was also at the center of the Vichy campaign for an improved national birth rate and healthy offspring. Children were the cornerstone of the nation's regeneration, taught to be active members of the state from birth. Boys were to be athletic and ready for physical work. Girls were to be trained in domestic labor and childrearing. All would grow up with France as their "fatherland," work as their service to their nation, and family as the drive for their ethical and moral choices. "[Children] are the hope of the new France," declared Paul Baudoin, Minister of Foreign Affairs under Vichy, "because adults are not ready to make a blank slate of their values. Children are the France of tomorrow. To remake France is above all else to remake French children" (quoted in Gerber 2018, 9).

The regenerated version of French masculinity that would produce these new generations of French children was to be virile, muscular and active, a vision informed both by classical notions of the male and an emphasis on the heroic French bodies of World War I. This view was held as much by the left as it was the right, that the French male body had failed against Nazi strength: "the majority of the troop officers were young reserve men recruited among the bourgeoisie, who manifested the defects of their class ... the soldiers of 1939 were not worth those of 1914; they did not oppose the invader with that stubborn resistance which marked the defenders of Warsaw, the Greek and Yugoslavian troops, or which the Russian soldiers show" wrote Pierre Cot (1941, 439; 446-47), air minister for the 
leftist Popular Front. In this regard, Vichy's proposed homme nouveau was not a solely conservative concern. However, it was under Vichy that this cruel summation of the suffering experienced by French soldiers on the battlefields in 1940 was used to articulate the need for a new France rooted in traditional national values and militaristic structures of power. This was symbolized most prominently by the figure of Pétain, the hero of Verdun, whose radio broadcasts and speeches repeatedly returned to the "problem" of the French race: "[W]e are setting out to destroy the fateful prestige of a purely bookish pseudo-culture, guide to idleness, and generator of uselessness... . The development of a sporting youth will address part of this problem ... to give back to the French race health, courage, discipline" (Pétain 1940, quoted in Tumblety 2012, 210).

Pétain's emphasis on the importance of physical activity and a "sporting youth" over intellectual pursuits was also not unique to the regime but had its origins in the physical culturists of the early twentieth century who emphasized body fitness as the path to proper social and moral hygiene. In particular, promoters of physical health had emerged following World War I with the rise of what Judith Surkis calls a "physiological politics" $(2007,104)$ where, as Tumblety puts it, the problem of post-war reconstruction was often fixed rhetorically and legislatively on the body itself. For a start the physical impact of the First World War on French men was all too visible. Not only had 1.3 million died in battle, but a million more drew invalid pensions as late as 1930. The figure of the disabled war veteran was omnipresent - in the Armistice Day parades, in the popular press, and on the street corners of French towns. $(2012,3)$

Spurred on also by concerns over a low birth rate in France following World War I, physical culture in France in the twenties and thirties was the intersection of a capitalist expansion of the health industry, the pan-Western rise in eugenic thinking amidst a fear of European racial 
degeneration, and the belief that social hygiene could be affected by a return to classical forms of fitness and muscularity. ${ }^{16}$ In France, this form was identifiably male, heterosexual and white, and it was this body that was perceived to be under threat in the interwar period. Such anxieties were discernible across public discourse, particularly in incredibly popular physical culture magazines such as Edmond Desbonnet's La culture physique which promoted social and moral hygiene as the ultimate goal of physical wellbeing. Such publications offered outlets to the prominent scientific figures who supported racial rejuvenation in the years before the war, particularly Georges Hébert, the promoter of the nationally renowned 'natural method' of outdoor exercise, and Dr. Paul Carton, a prolific holiday and fitness camp organizer who proclaimed Hébert's fitness routine a perfect match for his support of a healthy diet in a bid to "rebuild our race, ... its physical vigour and its spiritual worth!" (quoted in Tumblety 2012, 26). Fitness regimes and adverts for home gym equipment in such publications were also particularly prevalent in their contributions to ideals of physical fitness that Vichy would incorporate into its youth and athletics programs (Jackson 2003, 256), promoting strength in terms that proclaimed both a culture of gender division and classical aspirations: an advertisement for an elastic exercise band in 1937 editions of La culture physique proudly offered versions of the product labelled in ascending order of strength with the titles lady, adult, man, athlete, Hercules, and Super Hercules (Tumblety 2012, 25). France was body- and gender-obsessed well before Pétain's declarations of revolution and renewal.

Under Vichy, however, this emphasis on the relationship between physical fitness and masculinity translated into an authoritarian pursuit of France as a nation of the land and the family, with healthy offspring shown to be in close proximity to physical labor ready to usher France into a new future as part of a Nazi-governed Europe [fig. 2]. The apparent weakness of the military was even attributed to a pre-war decline in agricultural work: "this scandal [of 
French masculinity] required a redemption — a virile song of men working on the fields" (quoted in Jackson 2003, 329). The implicit idea that French soldiers-and French men more broadly—had been "softened" by contemporary French culture was recurrent under Vichy, a notion bolstered by the repeated characterization of the Third Republic as feminine in contrast to the "more national, more virile, more human" France of Vichy's imagination (Jackson 2003, 328).

\section{[image]}

Fig. 2, “Image d'Épinal," artist unknown, n.d., circa $1941^{17}$

The idea of virility as attained by labor "in the fields" is also one inherited from the physical culturists of the twenties and thirties. Hébert's natural method focused on the natural movements of the body and was designed to reintroduce physical activity into French masculinity as a counter to the "bookish" culture of the Third Republic. Hébert's goal was to push the male population towards an active, practical lifestyle that would help pass on this revived masculinity to future offspring, instilling them with a moral fortitude that would be represented by their athletic, muscular forms. By the time of Vichy, this practical activity was incorporated into the image of a French masculinity that not only worked the land but, in doing so, held at bay the forces deemed to be eroding and attacking French society [fig. 3].

\section{[image]}

Fig. 3 “Laissez-nous tranquilles!” (“Leave us in peace!”), G. Mazeyrie, 1941

\section{Molloy and the Male Body}


The unavoidable and persistent rhetoric of the male body in Vichy's propaganda offers a rich vein for thinking through Samuel Beckett's debilitated and impaired post-war bodies. In a stark inversion of Vichy's image of masculinity, Beckett's post-war male forms embrace decay, pursuing their own ideals of a male form stripped of its athletic and sexual potential. In the first novel of the trilogy, Molloy moves from abstaining from physical activity to a fantasy of degeneration and sexual debilitation through amputation. After running over Teddy the dog with his bicycle, Molloy joins the distraught Lousse in burying her pet with a shovel. However, due to his claimed physical impediment, Molloy does not participate in this physical labor:

It was she dug the hole because I couldn't, though I was the gentleman, because of my leg. That is to say I could have dug with a trowel, but not with a spade. For when you dig a grave one leg supports the weight of the body while the other, flexing and unflexing, drives the spade into the earth. Now my sick leg, I forget which, it's immaterial here, was in a condition neither to dig, because it was rigid, nor alone to support me, because it would have collapsed. I had so to speak only one leg at my disposal[.] (2009a, 33)

Though unable to dig, Molloy can quite precisely describe the physical movements that would occur if he did. Because his leg is "rigid" and unable to support his weight, Molloy cannot produce the natural movements expected when digging, nor participate in the expected gender role as the "gentleman" who asserts himself through physical activity. Molloy's refusal to participate in this depiction of the traditional male role both parodies and diminishes the very foundations on which this view of gender is predicated and, by extension, rejects the logic of value by which Vichy conceived its ideal French man. 
As the dog is buried, Molloy does not just abstain from the expected masculine activity, letting Lousse dig the hole on her own. He also fantasies about his own amputation, first the removal of his "rigid" leg, then the removal of his genitals:

I was virtually one-legged, and I would have been happier, livelier, amputated at the groin. And if they had removed a few testicles into the bargain I wouldn't have objected. For from such testicles as mine, dangling at mid-thigh at the end of a meagre cord, there was nothing more to be squeezed, not a drop. ... [W] orse still, they got in my way when I tried to walk, when I tried to sit down, as if my sick leg was not enough ... the best thing for me would have been for them to go, and I would have seen to it myself, with a knife or secateurs, but for my terror of physical pain and festered wounds[.] (33-34)

This imagining of degeneration specifically attacks the possibilities of virility and male sexual prowess, unsettling the locus of social, moral and political power ascribed to masculinity and the male form, and disrupting the discourse of the body that Vichy made central to its racial reimagining.

Though he wishes his genitals gone, the tropes of testicles and frailty again play a central role in producing signifiers of identity and another blackly humorous parody of the cherished Vichy trait of virility when Molloy describes his intercourse with the character named as both Ruth and Edith:

She had a hole between her legs ... and in this I put, or rather she put, my so-called virile member, not without difficulty, and I toiled and moiled until I discharged or gave up trying or was begged by her to stop. A mug's game in my opinion and tiring on top of that, in the long run ... Perhaps she too was a man, yet another of them. But in that case surely our testicles would have collided, while we writhed. Perhaps she held hers tight in her hand, on purpose to avoid it. (56) 
The possibility of reproduction is deferred through the combination of a language of sexual difficulty - the particular choice of "toil” also evoking the fieldwork cherished by Vichy's labor propaganda - and the introduction of a potential homosexual sex scene. Rather than healthy new offspring and the demonstration of a traditional, virile masculinity on Molloy's part (we never read Ruth/Edith's perspective), it is finally only bodily failure, the tiring physical assertion, that is imagined as the inevitable outcome of what is ruefully declared the "mug's game" of intercourse.

\section{Malone and Pétain: The Aging Male Body}

In the subsequent novel Malone Dies, the possibilities of physical exertion are further reduced as the novel focuses on the daily routines of the aged Malone in the confines of an institution bed: "Not only am I here, but I am looked after! This is how it is done now. The door half opens, a hand puts a dish on the little table left there for that purpose, takes away the dish of the previous day, and the door closes again. This is done for me every day, at the same time probably" (2010a, 9). Despite this schedule — or because of it—Malone does not know when he arrived in the space he occupies. Using his body and a minimal understanding of his own experiences, Malone estimates his age_— "I call myself an octogenarian, but I cannot prove it" (10) —and in so doing draws particular attention to the condition of the aging male body. With Vichy in mind, the propaganda that surrounded Pétain starts to loom in the characterization. This is not to say that Malone directly represents Pétain (the text's vague historical setting resists such an association); rather that the novel's descriptions reverse the ideals set out in the propaganda relating to Pétain's embodiment of a noble image of elder French masculinity through Malone's stark description of the aged, apparently infirm body receiving care. 
Pétain's significance for many of the French populace transcended political boundaries before the war, a seemingly ageless yet grandfatherly figure who was vital to the concept of French heroism. Crucially, Pétain had shepherded the nation through the horrors of World War I's most vicious fighting. Following the defeat of 1940, Pétain made his body — in tones that defied any limits of age — the symbol of French patriotism. As Ralph Albanese writes,

As an octogenarian, Pétain conjured the image of Corneille's [noble old men] ... in the collective imagination. Declaring on June 17, 1940, "I give to France the gift of my person, in order to alleviate her misfortune," Pétain justifies the armistice in light of the national drama of suffering and redemption. In effect, he indulges in selfsacrifice or, to use the Cornellian lexicon, he martyrs himself in the name of France. $(2008,75)$

Pétain's image as a heroic militaristic figure was replicated in the mobilization of older veterans under Vichy through the Legion of Combatants, founded in 1940 by Xavier Vallat with the order that they "must form groups down to the uttermost village in order to have the wise counsels of their leader of Verdun heeded and carried out" (quoted in Paxton 1972, 190). Vichy allowed the Legion, particularly its eldest members, to "play the civic role" (190) as a nationwide presence that emphasized the militaristic nature of Vichy, revived the martyrdom rhetoric of World War I, and facilitated a connection between the government and the public, particularly on matters of the Révolution nationale. With the physical presence of the Legion's members and a vast number of wartime publications devoted to the institution (Evleth 1999), the image of World War I's "disabled war veteran ... on the street corners of French towns" (Tumblety 2012, 3) was transformed into the image of the triumphant Pétain and of the revolution itself. Ever-present in Vichy, and always accompanied by a rhetoric of nobility and national strength, such an ideal of the older generation is ripe for Beckettian 
mockery. In the 1946 novella "The End," the elderly, homeless narrator laments his failure to secure lodgings despite "perfect[ing] a method of doffing my hat at once courteous and discreet" as part of his routine begging (2009b, 41). Though unsuccessful, the narrator develops his own "wise counsel" about public charity in a clear allusion to the war veterans so commonly seen across Europe during the period: "to tip one's hat is no easy matter ... I subsequently solved this problem, always fundamental in time of adversity, by wearing a kepi and saluting in military fashion." The trappings of age intervene, however, as the narrator immediately corrects himself: “no, that must be wrong, I don't know, I had my hat at the end." Amidst the confusions of memory, the beggar is nevertheless sure of one thing: "I never made the mistake of wearing medals" (41). For Beckett's beggar, alms are to be gathered through the ritual of begging, not sympathy for the image of a war victim.

Despite the "Cornellian lexicon" that surrounded Pétain, the physical aspects of aging — so central to much of Beckett's post-1945 work-occupied an uncomfortable place in Vichy's depiction of its leader. The regime often played down Pétain's age so as to resist notions of frailty or ill health, going so far on occasion to resist the "Lion of Verdun" moniker that he enjoyed during the interwar years; Pétain's blue eyes and upright posture were instead routinely emphasized in descriptions of his activities and speeches (Atkin 1998, 108-09). The central contradiction of the elderly Pétain venerated both for his youthful vigor and for his long service to France clearly did not escape Beckett's notice; consider again Beckett's characterization of Pétain as "the poor old misled man and hero of Verdun" (2011, 19; my emphasis). Such a pathetic rendering of the Vichy leader re-emerges in the body of the hospitalized Malone, a figure who is far from the upright, broad-shouldered image of Vichy's pro-Pétain propaganda:

My body is what is called, unadvisedly perhaps, impotent. There is virtually nothing it can do. Sometimes I miss not being able to crawl around anymore. But I am not much 
given to nostalgia. ... It is on my back, that is to say prostrate, no, supine, that I feel best, least bony. $(2010,10)$

I turn a little on my side, press my mouth against the pillow, and my nose, crush against the pillow my old hairs now no doubt as white as snow, pull the blankets over my head. I feel, deep down in my trunk, I cannot be more explicit, pains that seem new to me. (24)

The text rejects the very tradition of the noble old man on which Pétain himself capitalized. While Vichy masculinity was to be dutiful and physically powerful in old age, Beckett's Malone meticulously recounts the small movements of his aging body to emphasize debilitation, limitation and pains.

\section{"Why should I have a sex?": The Unnamable}

Beckett's decomposing male form finds its apotheosis in The Unnamable. In particular, it is Mahood, the "vice-exister" identified with a near homonym of manhood that offers the most striking image of the decayed male body. "I feel my back straight," the narrator reports as his selfhood begins its steady merger with Mahood's, "my neck stiff and free of twist and up on top of it the head, like the ball of the cup-and-ball in its cup at the end of the stick" $(2010$, 15). As the image begins to crystallize, an only vaguely human, or perhaps previously human, form is conjured:

No, no beard. No hair either. It is a great smooth ball I carry on my shoulders, featureless but for the eyes, of which only the sockets remain. And were it not for the distant testimony of my palms, my soles, which I have not yet been able to quash, I would gladly give myself the shape, if not the consistency, of an egg-with two holes 
no matter where to prevent it from bursting, for the consistency is more like that of mucilage. (15)

Eventually, it is revealed that the narrator has achieved what Molloy so desired, the removal of his genitals and so the final signifier of masculinity: "Why should I have a sex, who have no longer a nose? All those things have fallen, all the things that stick out, with my eyes, my hair-without leaving a trace" (16). Rather than becoming the ideal muscular, heroic form imagined in Vichy propaganda, a being that would "gladly give" itself the shape "of an egg" is presented as the source and vehicle of expression. Stripped of physical form, the "egg" dismisses all identifiers of sex or biology, subsuming the traditional associations of the egg with reproduction and renewal into a grotesque visage of stasis and silence. Such a violent dissolving of the body and the narrator's "sex" denotes a rejection of everything the physical body represents, disrupting the very basis of narratives of race and gender, of human perfectibility and bodily prowess. ${ }^{18}$

The emphasis on the negation of gender is also resonant here with Vichy's drive to solidify normative gender roles. Again, this had its origins in interwar rhetoric that Vichy gave platform to during the war. In his 1935 treatise on modernity and the human body, Man the Unknown, Alexis Carrel wrote: "The sexes have again to be clearly defined. Each individual must either be male or female, and never manifest the sexual tendencies, mental characteristics, and ambitions of the opposite sex" (quoted in Jackson 2003, 32). Under Vichy, this emphasis on masculinity, virility and physical prowess also carried with it an implicit and stereotypical rejection of non-normative sexualities. The assertion of specific gender roles - designed to re-enforce familial values and promote the production of offspring - meant that any sexuality that was not heterosexual was deemed a slight against the vision of France that the Révolution nationale promoted. The Unnamable's rejection of reproductive body parts disrupts this Vichyite impulse to separate the sexes, rendering the 
signifiers of "sex" no more important than a "nose" and offspring an impossible outcome of existence.

Such an aesthetics of physical decline that Beckett is drawn to following World War II marks a sharp turn against both pre-war French physical culture and the pervasive image of masculinity through which Vichy hoped to restore the French race and nation. In most readings, Beckett's degenerating bodies are recognized as extreme depictions of suffering which, in their extremity, speak to a central aspect of the human condition. For Kathryn White, for example, Beckett's trilogy offers an articulation of the inevitable facticity of physical human existence in a manner that is ultimately redemptive:

Beckett magnifies the infirmities that affect us all; hence, this amplification of physical malaise enables us to relate to the characters, as we recognize that their pain is an illustrated intensification of our own suffering. Beckett's representation of the reality of the human condition ... forces us to acknowledge the inadequacy of the physical body and recognize its inevitable failure. $(2011,9)$

Whilst some form of empathetic relation may be established between Beckettian character and Beckettian reader, it is important to recognize that White here sounds out a paradox within this humanistic notion that Beckett is representing "the human condition" in all its feeble physicality. How might Beckett's be a "representation of the reality of the human condition" yet also offer an "illustrated intensification of our own suffering"? The term "intensification" is undoubtedly key here; Beckett intensifies, parodies and stylizes physical degeneration such that the "relat[ability]," the "our," is placed under duress. Beckett offers a physical degeneration that can be identified in the recurrences of illness, age and amputation as very much post-war and, as I have shown, post-Vichy. Yet the texts also produce the fantastical images of a post- or non-human form whose distinguishing physical features have, come The Unnamable, simply disappeared "without a trace." Though the novels replace the 
fantasy of bodily prowess with bodily decay, they ultimately generate bodily forms which are as little representative of the human form as the idealized vision of physicality that Vichy constructed for the French people. The novels not only point to the universal fact that the human body can and does degenerate, but also offer a sustained and unremitting counter to particular heroic notions of the physical form and the normative attachment of value to physical fitness which saw certain bodies excluded from Vichy's vision of France. The novels chart the very degeneration that so many mid-century ideologies feared or diagnosed within European society, one which was perceived by Vichy to be the root of the defeat of France's fighting bodies. In Molloy, Moran even adopts the language of post-defeat "regeneration" found throughout Vichy propaganda: "to be literally incapable of motion at last, that must be something! ... And to dread death like a regeneration" (146). Rather than "renewal," the language of Vichy is recycled to dismiss any ideals of the body as a site of revival or restoration.

By reading the states of existence found throughout Beckett's prose against the Vichy emphasis on the virile male form, Beckett's post-war writing produces a counter-history that gives voice to human forms rejected by mid-century ideologies of the body, including those of the dead and dying bodies of the 1940 defeat of France that Pétain and others characterized as products of a weak and decadent Republic. Such connections do not limit Beckett's degenerating bodily forms to a historical situation, nor to a narrow conception of resistance that ultimately seeks a redemption in the bodies described. The bodies of the trilogy are, after all, suffering. However, by reading these states of existence against the emphasis on the healthy, distinctly male, and infinitely perfectible muscular form that emerged from the anxieties of the interwar period, and against its manifestation in the Vichy program of national regeneration, Beckett's work takes on significant political and historical dimensions. Not only degrading but fantasizing further impairment, Beckett's bodies mock, aggravate and 
challenge the idolization of a male form that is underpinned by the essentialisms that also allowed Vichy to participate in, and sanction its own part in, the deportation and rejection of excluded bodies. By attending to the reality of Vichy's drive towards the ideal male body, we can read in Beckett's prose a counterpoint through which images of physical degradation emerge as a resistance to the association between the body and hereditary, hierarchical, and political power, and to the conflation of bodily perfection with moral and social value or structures of identity.

\section{Notes}

${ }^{1}$ Vichy's politics and history have been the subject of sustained study in Anglophone criticism since Robert Paxton's (1972) seminal work on the collaborationist regime. Specific criticism devoted to the Révolution nationale has been a more recent occurrence, with Julian Jackson (2003) incorporating the programme fully into his extended study of France's war years. Debbie Lackerstein's (2012) work has brought to light the particular continuities that exist between the politics of the thirties in France and that of Vichy, as well as the origins of the regime's vision of the nation from those who rejected the Third Republic. French criticism began earlier, representative of which are Robert Aron (1954) and Eberhard Jäckel (1968). The publication of Pétain's speeches (1989) enabled a new generation of French critics to examine the regime.

${ }^{2}$ Beckett's writing as "resistant" has been treated in terms of the "courageous" as a generic aesthetic position by Alan Badiou (2003), though Jackie Blackman sees Badiou's position as inflected by the sense in which "Beckett's resistance" is to "the prevailing culture of complacency and indifference [of] wartime and after" $(2009,71)$. Barbara Will (2014) more explicitly marries Badiou's Beckett with reflections on resistance as a position in the history of French political thought. 
${ }^{3}$ McMullan's work joins Ulrika Maude's (2009) as touchstones in explorations of the affective possibilities of Beckett's use of the body. This aspect of Beckett's drama specifically has been re-emphasised in Charlotta P. Einarsson's recent work (2017).

${ }^{4}$ The nature of prose as a specific medium for Beckett's linguistic degeneration has invited a series of engagements, particularly in terms of the evocations of death and the dissolution of meaning that the texts enact. Christopher Ricks (1993) sees Beckett's syntactical experimentation as charting the question of personality's relationship to death. Kathryn White (2011) develops this to see decay as the primary element of the Beckettian aesthetic. Elsewhere, preceding Maude's incorporation of the question of technology, Yoshiki Tajiri (2007) examines the Beckettian body through a discourse of physical and linguistic prosthesis that reads Beckett's rendering of organs and senses as important aspects of the modernist understanding of the body as a site of conflict.

${ }^{5}$ Work on Beckett's "Irishness" has become a keystone in contemporary Beckett scholarship. Early works on the subject include those of David Lloyd (1992) and John P. Harrington (1993). Alongside Patrick Bixby's study of the prose, recent criticism includes Emilie Morin's Samuel Beckett and the Problem of Irishness (2009), Seán Kennedy’s contributions and editorial work (2010a; 2010b; 2015), Fergal Whelan's interrogation of Beckett's protestant heritage (2018) and James McNaughton's demonstration of the idea of “aftermath" as a nexus of aesthetic, political and historical effects in Beckett's work (2018).

${ }^{6}$ Given Becket's foreign status and the couple's involvements with the Resistance, the Vichy regime presented a real threat both to their personal wellbeing and to the France they hoped to live in. Both Beckett and Suzanne were also often thought to look Jewish by locals in Southern France. "Many villagers supposed that one or other of the Beckett couple must be Jewish [or that he] must be subject to the regulation of résidence forcée, according to which 
foreigners in Vichy France were obliged to live at a distance from the sea" (Knowlson 1996, $320)$.

${ }^{7}$ Like most of the work by Perloff, Salisbury and Gibson, I focus on the prose in this article. Despite the wealth of work done on Beckett's theatre, there is much scope and need for an examination of the early drama in the context of wartime and post-war France.

${ }^{8}$ This also raises the question as to why Beckett's novel Watt, written during the war, is not the primary focus on analyses of Beckett's engagement with wartime propaganda. In part, I suggest that it took the defeat of Vichy and the return to the Republic for the magnitude of Vichy's ideology to become apparent. The Watt manuscripts and published text are also far less concerned with the body compared to the trilogy, and as such do not suit the particular focus I propose here. Nevertheless, Watt and propaganda is an important area, and has been addressed by McNaughton $(2010 ; 2018)$ and myself (forthcoming) in terms of the novel's deconstruction of narrative techniques akin to those found in Nazi propaganda.

${ }^{9}$ A noteworthy exception in Beckett's rejection of Vichy discourse is his friend Georges Belmont (Pelorson before the war) who was the Vichy minister for propaganda. Beckett does not appear to have ever openly condemned Belmont's war-time activities. This may well be out of embarrassment, even sympathy, at his own friend also being a "poor [...] misled man," but this remains speculation without direct evidence. Beckett's published text includes a reference to the day "Darly" died, an allusion to the death of his Saint-Lô colleague Arthur Darley. As Van Hulle $(2011,81)$ demonstrates, Beckett used "McKee," a reference to another Saint-Lô colleague, in an earlier draft.

${ }^{10}$ For a discussion of Belmont/Pelorson's pre, war-time, and post-war activities, as well as his relationship with Beckett, see Giroud (2002).

${ }^{11}$ See Chapter 8, "What is Fascism?" in Paxton (2004) on how fascism and authoritarianism overlap and differ. 
${ }^{12}$ Vichy only promoted one official "eugenicist measure" which focused on the Vichy preoccupation with France's birth rate by restricting alcohol and enforcing marriage-related medical check-ups to guard against venereal disease (Jackson 2003, 329).

${ }^{13}$ Paxton (2004) has done much work to establish the particular strain of right-wing thinking that pervaded Vichy and how it must be rendered distinct from Nazism. That Vichy was acting 'for France' is also not to defend the post-war claims made in Vichy's favour. Indeed, this was the defence used by many members of the regime during the trials that followed the war, that Vichy was protecting France against German dominance. If this was true for some of the traditionalist core of Vichy, it was a quite different case among the elite circle. "I hope for a German victory", declared Pierre Laval in a radio broadcast during the war (quoted in Marrus and Paxton 1995, 231).

${ }^{14}$ By 1942, the Germans agreed to the establishment of a Vichy-run, single company "with exclusive rights to edit and distribute all newsreels in France” (Jackson 2003, 254-55), meaning that the Révolution nationale continued to be promoted despite Nazi occupation of the south in the later stages of the war.

${ }^{15}$ As Gibson (2015) demonstrates, Beckett makes a series of comments to friends in letters from the thirties that suggest he became acutely aware of the popularity and ideas of Charles Maurras and other French right-wing thinkers, and so would have remained cognizant of the intentions of the 'revolution' and its potential supporters throughout France. Beckett's welldocumented sensitivities to propaganda developed during his formative years under the cultural nationalism of the Irish Free State and during his tour of Nazi Germany in 1936-37. Beckett's engagements with the Irish Free State politics are examined by Bixby and Kennedy, among others. For Beckett's responses to Nazi propaganda, see McNaughton (2010; 2018), Nixon (2011) and Davies (forthcoming). Though evocative of measures in interwar Germany, Vichy's National Revolution would also have been strikingly reminiscent 
of aspects of the Irish Free State, particularly the emphasis on Catholicism as the backbone of social values, its drive towards an agrarian economy, and its focus on the moral values of patriotism and family values. The Free State politics which Beckett particularly rejected-its policies of censorship, sexual repression (see Houston 2018), and traditionalism—would also have rendered the "revolution" propaganda of wartime France alarmingly resonant.

${ }^{16}$ Kennedy has argued convincingly that the prevalence of 'degeneration theory', particularly the work of Max Nordeau, could not have escaped Beckett's notice given its popularity not only in France but also in Nazi Germany and in the race discourse of figures like W. B. Yeats $(2015,195-99)$.

${ }^{17}$ Vichy's use of images described as "Image d'Épinal" was an intensification of propaganda practices from before World War I. For a broader discussion of such propaganda in France during the twentieth century, see Holman and Kelly (2000).

${ }^{18}$ For a discussion of the role of sex and sexuality in Beckett's aesthetic, see Stewart (2011). 


\section{Works Cited}

Albanese, Ralph. 2008. "Republican School Discourse and the Construction of French Cultural Identity: La Fontaine and Corneille as Case Studies.” In Culture Wars and Literature in the French Third Republic, edited by Gilbert D. Chaitin, 65-82. Newcastle: Cambridge Scholars.

Aron, Robert. 1954. Histoire de Vichy, 1940-1944. Paris: Fayard.

Atkin, Nicholas. 1998. Pétain. Harlow: Longman.

Badiou, Alain. 2003. On Beckett. Manchester: Clinamen Press.

Beckett, Samuel. 1995. The Complete Short Prose 1929-1989, edited by S. E. Gontarski. New York: Grove Press.

—. Molloy. London: Faber \& Faber.

—. 2009b. The Expelled/The Calmative/The End/First Love. London: Faber \& Faber.

—. 2010a. Malone Dies. London: Faber \& Faber.

—. 2010b. The Unnamable. London: Faber \& Faber.

—. 2011. The Letters of Samuel Beckett, 1941-1956, edited by George Craig, Martha Dow Fehsenfeld, Dan Gunn and Lois More Overbeck. Cambridge: Cambridge University Press.

Blackman, Jackie. 2008. "Post-war Beckett: Resistance, Commitment or Communist Krap?" In Beckett and Ethics, edited by Russell Smith, 68-85. London: Bloomsbury.

Cot, Pierre. 1941. "Morale in France during the war." American Journal of Sociology 47, no. 3: 429-51.

Davies, William. Forthcoming. “Watt and the Politics of Form.” In Beckett Beyond the Normal, edited by Seán Kennedy. Edinburgh: Edinburgh University Press. 
Dwan, Lisa. 25 July 2014. "Playing Beckett.” The Telegraph. Accessed August 2018. https://www.telegraph.co.uk/culture/theatre/10946793/Playing-Beckett-First-Imblindfolded-then-I-place-my-head-in-a-vice.html.

Einarsson, Charlotta P. 2017. A Theatre of Affect: The Corporeal Turn in Samuel Beckett's Drama. Stuttgart: Ibidem.

Evleth, Donna. 1999. The Authorized Press in Vichy and German-Occupied France, 19401944: A Bibliography. Westport, CT: Greenword Press.

Gerber, Michael. 2018. “Vichy’s New Man: National Regeneration and Historical Revisionism in French Education, 1940-1944.” Unpublished thesis. Ohio University, OhioLINK Electronic Theses and Dissertations Center.

[https://etd.ohiolink.edu/pg_10?0::NO:10:P10_ACCESSION_NUM:ouhonors152450 $1870504622]$.

Gibson, Andrew. 2010. Samuel Beckett: A Critical Life. London: Reaktion.

—. 2014. "French Beckett and French Literary Politics 1945-52." In The Edinburgh Companion to Samuel Beckett and the Arts, edited by S. E. Gontarski, 103-16. Edinburgh: Edinburgh University Press.

—. 2015. "Beckett, Vichy, Maurras, and the Body: Premier amour and Nouvelles." Irish University Review 45, no. 2: 281-301.

Giroud, Vincent. 2000. "Transition to Vichy: The Case of Georges Pelorson." Modernism/Modernity 7, no. 2: 221-48.

Gordon, Lois. 1998. The World of Samuel Beckett, 1906-1946. New Haven and London: Yale University Press.

Harrington, John P. 1991. The Irish Beckett. Syracuse, NY: Syracuse University Press. 
Holman, Valeria, and Debra Kelly, eds. 2000. "Introduction: Myth and Metaphor: The Power of Propaganda in Twentieth-Century Warfare." In France at War in the Twentieth Century: Propaganda, Myth and Metaphor, 1-14. New York: Berghahn Books.

Houston, Lloyd Meadhbh. 2018. “'Sterilization of the mind and apotheosis of the litter': Beckett, Censorship, and Fertility.” The Review of English Studies 69, no. 290: 54664.

Jäckel, Eberhard. 1968. La France dans l'Europe de Hitler. Paris: Fayard.

Jackson, Julian. 2003. France: The Dark Years: 1940-1944. Oxford: Oxford University Press.

Junyk, Ihor. 2013. Foreign Modernism: Cosmopolitanism, Identity, and Style in Paris. Toronto: University of Toronto Press.

Kedward, H. R. 1993. In Search of the Maquis: Rural Resistance in Sourthern France 19421944. Oxford: Oxford University Press.

Kennedy, Seán, ed. 2010. Beckett and Ireland. Cambridge: Cambridge University Press.

—. 2015. “"Humanity in Ruins': Beckett and History.” In The New Cambridge Companion to Samuel Beckett, edited by Dirk Van Hulle, 185-200. Cambridge: Cambridge University Press.

Kennedy, Seán and Katherine Weiss, eds. 2009. Samuel Beckett: History, Memory, Archive. Basingstoke: Palgrave Macmillan.

Knowlson, James. 1996. Damned to Fame: The Life of Samuel Beckett. London: Bloomsbury.

Lloyd, David. 1992. Anomalous States: Irish Writing and the Post-Colonial Moment. Durham, NC: Duke University Press.

Marrus, Michael R. and Robert O. Paxton. 1995. Vichy France and the Jews. Stanford: Stanford University Press. 
Maude, Ulrika. 2009. Beckett, Technology and the Body. Cambridge: Cambridge University Press.

McMullan, Anna. 2010. Performing Embodiment in Samuel Beckett's Drama. New York and London: Routledge.

McNaughton, James. 2010. "Beckett's 'Brilliant Obscurantics': Watt and the Problem of Propaganda.” In Samuel Beckett: History, Memory, Archive, edited by Seán Kennedy and Katherine Weiss, 47-69. Basingstoke: Palgrave Macmillan.

—. 2018. Samuel Beckett and the Politics of Aftermath. Oxford: Oxford University Press. Moorjani, Angela. 2015. “Molloy, Malone Dies, The Unnamable: The Novel Reshaped.” In The New Cambridge Companion to Samuel Beckett, edited by Dirk Van Hulle, 19-32. Cambridge: Cambridge University Press.

Morin, Emilie. 2009. Samuel Beckett and the Problem of Irishness. Basingstoke: Palgrave Macmillan.

—. 2017. Samuel Beckett's Political Imagination. Cambridge: Cambridge University Press.

Nixon, Mark. 2011. Samuel Beckett's German Diaries, 1936-7. London: Bloomsbury.

Paxton, Robert O. 2004. The Anatomy of Fascism. New York: Alfred A. Knopf.

—. 1972. Vichy France: Old Guard and New Order, 1940-1944. London: Barrie \& Jenkins.

Perloff, Marjorie. 1996. "Witt-Watt: The Language of Resistance / The Resistance of Language.” In Wittgenstein's Ladder, 115-44. Chicago: University of Chicago Press. —. 2005. "In Love with Hiding: Samuel Beckett's War.” The Iowa Review 35, no. 1: 76103.

Pétain, Phillippe. 1989 Discours aux Français, 17 juin 1940-20 août 1944, edited by Albin Michel. Luçon: Imprimerie Pollina. 
Ricks, Christopher. 1993. Beckett's Dying Words. Oxford: Oxford University Press.

Rousso, Henri. 1991. The Vichy Syndrome: History and Memory in France Since 1944.

Translated by Arthur Goldhammer. Cambridge, MA: Harvard University Press.

Russel, Rachel. 2002. "Ethical Bodies." In The Body, Culture and Society: An Introduction, edited by Philip Hancock, Bill Hughes, Elizabeth Jagger, Kevin Paterson, Rachel Russel, Emmanuelle Tulle-Winton, and Melissa Tyler, 101-16. Buckingham: Open University Press.

Salisbury, Laura. 2014. “Gloria SMH and Beckett's Linguistic Encryptions.” In The Edinburgh Companion to Beckett and the Arts, edited by S. E. Gontarski, 153-69. Edinburgh: Edinburgh University Press.

Stewart, Paul. 2011. Sex and Aesthetics in Samuel Beckett's Work. New York: Palgrave. Surkis, Judith. 2007. "Enemies Within: Venereal Disease and the Defense of French Masculinity between the Wars." In French Masculinities: History, Culture and Politics, edited by Christopher E. Forth and Bertrand Taither, 103-22. Basingstoke: Palgrave Macmillan.

Tajiri, Yoshiki. 2007. Samuel Beckett and the Prosthetic Body. Basingstoke: Palgrave Macmillan.

Tumblety, Joan. 2012. Remaking the Male Body: Masculinity and the Uses of Physical Culture in Interwar and Vichy France. Oxford: Oxford University Press.

Van Hulle, Dirk. 2011. The Making of Samuel Beckett's Stirrings Still / Soubresauts and Comment Dire / What Is the Word. London: Bloomsbury.

Weller, Shane. 2009. “'Orgy of False Being Life in Common': Beckett and the Politics of Death.” In Beckett and Death, edited by Steven Barfield, Matthew Feldman and Philip Tew, 31-49. London: Bloomsbury.

Whelan, Fergal. 2018. Samuel Beckett and the Protestant Imagination. Stuttgart: Ibidem. White, Kathryn. 2011. Beckett and Decay. London: Bloomsbury. 
Will, Barbara. 2014. "The Resistance Syndrome: Alain Badiou on Samuel Beckett." South Central Review 31, no. 1: 114-29.

\section{Images}

Figure 1, "Révolution nationale," n.d., circa 1940. Poster designed by R. Vachet. Avignon: National Revolution Propaganda Center.

Figure 2, "Image d'Épinal," artist unknown, n.d., circa 1941

Figure 3, “Laissez-nous tranquilles!" G. Mazeyrie, 1941 